\title{
FUTURE TRENDS IN THE HOSPITALITY INDUSTRY: AN ANALYSIS FROM THE CONSUMERS' POINT OF VIEW
}

\author{
Zélia Breda \\ Catarina Pacheco \\ Gorete Dinis
}

https://doi.org/10.20867/tosee.05.9

\begin{abstract}
Purpose - The tourism sector is influenced by many factors, which affect not only the tourism economy but also induce changes in tourists, transforming their behaviour. Hotel establishments, part of the tourism system, operate in an environment which suffers influences and is highly competitive. Due to this, it is important to have strategic planning that allows anticipating changes or threats, namely paying attention to consumers' needs and expectations. The goal of this study is to analyze consumer behaviour regarding Portuguese hotel establishments, identifying trends that are influencing the sector, from the demand perspective.

Methodology - An online questionnaire was applied to guests of hotel establishments, with 305 valid answers. The questionnaire was developed in line with the decision-making process, by identifying the motivation, planning process, reservation, satisfaction, recommendation, and perspectives on the future of the hospitality industry. It also includes questions to draw the sociodemographic profile of the consumer. Univariate, bivariate and multivariate analysis of the collected data was performed through the SPSS software.

Findings - Results suggest that the Internet is relevant for tourists to plan and book their stay, and the most significant attributes for their decision-making are service quality, price, and location. It was further concluded that technology and personalization are the areas that create more expectations in the consumers concerning the future of hotel establishments. Considering the characteristics of the new generations, namely the millennials, who have higher technology requirements, hotel managers should consider a greater integration of technology in their establishments in order to increase the quality of the guest experience and, consequently, their satisfaction. In addition, it is recommended that hotel establishments not only sell rooms but an experience, which should be more personalized and integrated with the local community.

Contribution - The empirical study allowed obtaining a broad view on how consumers behave in the pre and post experience, as well as to know the attributes that they consider important for the choice of accommodation, and their satisfaction. This analysis allows managers to deepen their knowledge about their clients, better understanding how they plan and book their stay, as well as identifying the strengths and weaknesses of the accommodation, useful for understanding where they should allocate or withdraw resources.
\end{abstract}

Keywords Tourism, consumer behavior, decision-making process, trends, hospitality industry, Portugal 
ToSEE - Tourism in Southern and Eastern Europe, Vol. 5, pp. 139-162, 2019

Z. Breda, C. Pacheco, G. Dinis: FUTURE TRENDS IN THE HOSPITALITY INDUSTRY: AN ...

\section{INTRODUCTION}

Tourism is an important economic sector worldwide, having experienced rapid and virtually continuous growth, from 25 million international tourist arrivals in 1950 to 1.4 billion in 2018 (UWNTO, 2019). It is expected to continue to grow, reaching 1.8 billion international tourist arrivals by 2030 (UWNTO, 2011). In Portugal, the number of guests reached 24 million in 2017 and overnight stays reached 65.4 million (INE, 2018). The greater importance of the sector leads to the need for long-term strategic planning, which allows a sustainable development not only of the destination but also of the different stakeholders that integrate it and make up the tourism supply (Baumgarten, 2006; Clarke and Chen, 2007).

Various events, such as political instability, terrorism, consumer changes, economic problems, among others, are influencing the volume of tourism but also shaping tourism demand. It is, therefore, relevant to analyze two dimensions: the trends that result from changes at the consumer level and the trends emerging from the external environment that influence tourism, for example by changing available resources, demand patterns or legislation (Costa and Buhalis, 2006a, 2006b). In this context, the area of consumer behavior becomes essential to know the tourists and their decision making, allowing the definition of guidelines to develop, promote and sell tourism products (Swarbrooke and Horner, 2007)

According to Fesenmaier and Gretzel (2004), we can not predict the future nor can fully prepare for it, however, if we withdraw information from current experiences, we can prepare ourselves for change. Given that studies on the future of accommodation are still scarce, especially the ones focusing on the consumer perspective, this study tries to make a contribution, by analyzing the current behavior of consumers regarding Portuguese hotel establishments, analyzing the external environment that surrounds them, and understand what challenges and opportunities this sector faces, in order to be able to develop proactive strategies.

\section{THEORETICAL FRAMEWORK}

According to Kotler et al. (2011), firms that understand exactly how their consumers respond to the characteristics of their products, prices, and advertising have a great advantage over their competitors. Buttle (1991), in turn, states that one of the advantages of studying consumer behavior is the ability to predict and control demand more efficiently. Consumer decision-making, seen as a complex process in the tourism sector given its intangible characteristics (Zeithaml et al., 1985; Swarbrooke and Horner, 2007), has distinct phases that are interrelated and influenced by personal factors, such as age or occupation (Mathieson and Wall, 1982), and external factors that are neither controlled by the tourists nor by the supply side, such as strikes, climate, diseases or wars (Swarbrooke and Horner, 2007; Wall and Mathieson, 2006). Motivations are considered determinants of consumer behaviour since they are the driving force that compels tourists to travel (Baloglu and Uysal, 1996). There are several models that attempt to analyze and identify different types of motivations (e.g. Plog, 1974; Mathieson and Wall, 1982; 
ToSEE - Tourism in Southern and Eastern Europe, Vol. 5, pp. 139-162, 2019

Z. Breda, C. Pacheco, G. Dinis: FUTURE TRENDS IN THE HOSPITALITY INDUSTRY: AN

Middleton and Clarke, 2001; Kotler and Keller, 2006), given that identifying and understanding the motivations of tourists lead to a better definition of the tourist supply.

When talking about motivations, it is important to discuss push and pull factors (Baloglu and Uysal, 1996). Push factors are defined as sociopsychological motivations that are responsible for people wanting to travel, while pull factors influence where and how they travel (Crompton, 1979; Baloglu and Uysal, 1996; Yoon and Uysal, 2005). Thus, while push factors are related to something intangible and intrinsic to the consumer, pull factors are related to characteristics and attributes of the destination that attract the consumer, such as beaches, historical or cultural attractions, available infrastructures, entertainment opportunities or natural landscapes (Crompton, 1979; Baloglu and Uysal, 1996; Yoon and Uysal, 2005).

Once tourists feel the urge to travel, they start searching for information in different sources, which can be classified into internal or external. The search for information usually begins internally, in the mind of the consumers, in search of past experiences, either in the same destination or in similar destinations and, when tourists consider that this information is not enough, they resort to external sources (Chen, 2000; Chen and Gursoy, 2000; Fodness and Murray, 1997, 1999), whose choice can be influenced by personal, situational and product-related factors (Fodness and Murray, 1999). The Internet is the most widely used external source, especially by younger people (Beldona and Cobanoglu, 2007; Hernández et al., 2011) and people with higher levels of education and income (Qi et al., 2013), with diverse websites being used in different stages of the information search. It is highlighted the growing importance of social media in tourism, which represents a relevant part of the results in the search for information (Verna et al. 2012).

After the tourist experience, tourists make their evaluation of the trip, which can translate into consumer satisfaction and loyalty. Satisfaction is a well-studied topic in the literature. Since satisfied customers result in greater profits for companies, it is necessary to know the consumer so that their expectations on the pre-travel phase are met by their perception in the post-travel (Anderson et al., 1994; Cronin et al., 2000). Studies focusing on the hotel sector analyzing the needs of consumers evidence attributes that are considered important to guests, such as cleanliness, location, price, safety, quality of service or reputation of the hotel or hotel chain (Table 1).

Table 1: Determining attributes for the hotel choice

\begin{tabular}{|l|l|}
\hline Attributes & Studies \\
\hline Cleanliness & $\begin{array}{l}\text { Atkinson (1988); Knutson (1988); Saleh and Ryan } \\
(1992)\end{array}$ \\
\hline $\begin{array}{l}\text { Quality of rooms (comfort, } \\
\text { cleanliness, space) }\end{array}$ & $\begin{array}{l}\text { Cadotte and Turgeon (1988); Chaves et al. (2012); } \\
\text { Knutson (1988); Saleh and Ryan (1992) }\end{array}$ \\
\hline $\begin{array}{l}\text { Convenient location and } \\
\text { accessibility }\end{array}$ & $\begin{array}{l}\text { Ananth et al. (1992); Chaves et al. (2012); LeBlanc } \\
\text { and Nguyen (1996); Rivers et al. (1991) }\end{array}$ \\
\hline Safety and protection & $\begin{array}{l}\text { Ananth et al. (1992); Atkinson (1988); Cadotte and } \\
\text { Turgeon (1988); Knutson (1988) }\end{array}$ \\
\hline
\end{tabular}


ToSEE - Tourism in Southern and Eastern Europe, Vol. 5, pp. 139-162, 2019

Z. Breda, C. Pacheco, G. Dinis: FUTURE TRENDS IN THE HOSPITALITY INDUSTRY: AN ...

\begin{tabular}{|l|l|}
\hline Attributes & Studies \\
\hline $\begin{array}{l}\text { Friendliness, empathy, knowledge } \\
\text { and readiness of the staff }\end{array}$ & $\begin{array}{l}\text { Ananth et al. (1992); Atkinson (1988); Cadotte and } \\
\text { Turgeon (1988); Chaves et al. (2012); Knutson (1988); } \\
\text { LeBlanc and Nguyen (1996); Rivers et al. (1991); } \\
\text { Saleh and Ryan (1992) }\end{array}$ \\
\hline Value for money & Atkinson (1988); Choi and Chu (2001) \\
\hline Exterior design / interior decoration & Saleh and Ryan (1992); Wilensky and Buttle (1988) \\
\hline Use of sustainable practices & Chen (2014); Han et al. (2011) \\
\hline Use of technology & $\begin{array}{l}\text { Beldona and Cobanoglu (2007); Cobanoglu et al. } \\
\text { (2011); Zhou et al. (2014) }\end{array}$ \\
\hline Wi-fi available & $\begin{array}{l}\text { Bulchand-Gidumal et al. (2011); Chen (2014); } \\
\text { Radojevic et al. (2015); Zhou et al. (2014) }\end{array}$ \\
\hline
\end{tabular}

Source: Adapted from Poon and Lock-Teng Low (2005); Radojevic et al. (2015)

The importance of wi-fi has been mentioned in more recent publications, being something that consumers appreciate and take into consideration in their accommodation choice. In addition, the use of technology by hotels is considered important, having an impact both on consumer choice and satisfaction (Beldona and Cobanoglu, 2007; Cobanoglu et al., 2011). Beldona and Cobanoglu (2007) argue that the hotel industry is usually slow in adopting new technologies, perhaps because it does not perceive its importance in hotel performance. Growing concern for the environment has also led consumers to choose hotels that have environmentally friendly practices (Chen, 2014; Han et al., 2011).

Dolnicar and Otter (2003) reviewed 21 articles, published between 1984 and 2000, in order to understand what influenced consumers' choice of accommodation and extracted 173 attributes. These were grouped into ten groups: image, price/value, services, hotel, room, food and beverage, marketing, security, location, and others. Based on the review, the authors pointed out the main attributes of a hotel, such as: convenient location, quality of service, reputation, staff empathy, price, room cleanliness, value for money, cleanliness of the hotel, security, pool, bed comfort, parking and room size (Dolnicar and Otter, 2003). It is, however, necessary to take into account that factors such as age, gender and reason for travel influence decision criteria for hotel choice (Mccleary et al., 1993). For example, some articles address the differences in consumer decision behaviour between leisure and business travellers, with professional motivation and location being more important for business travellers (Mccleary et al., 1993), while safety, personal interactions and price were considered the most significant for leisure travellers (Yavas and Babakus, 2005).

In terms of loyalty, this topic is also referred to as essential for greater business competitiveness, since having loyal customers is less expensive than acquiring new ones (Kandampully et al., 2011). One of the dimensions of loyalty is the behavioral dimension (Woodside et al., 1989), which relates to when the consumer returns to buy from the same supplier and produces positive word of mouth (WOM). WOM, which relates to recommendations independent of commercial influence made among consumers, gained a new dimension with the Internet, evolving into eWOM (electronic word of mouth), with recommendations being written and published online, reaching a broader audience and being available for a long period of time. Helping other tourists, sharing 
ToSEE - Tourism in Southern and Eastern Europe, Vol. 5, pp. 139-162, 2019

Z. Breda, C. Pacheco, G. Dinis: FUTURE TRENDS IN THE HOSPITALITY INDUSTRY: AN ...

dissatisfaction or gaining a sense of belonging to a community are some of the reasons consumers state to produce eWOM (Serra Cantallops et al., 2014; Yen et al., 2015). Comparability of hotels, influence on the choice of hotel or greater credibility are some of the impacts of eWOM (Serra Cantallops et al., 2014).

The shift between the old and the new tourism, pointed out by Poon (1993), reveals that a new type of consumer is one of the main drivers of change. New tourists, seen as more experienced, spontaneous and independent, seek authenticity and tend to create a demand that differs from mass tourism associated with old tourists (Poon, 1993; Yeoman, 2006; Pirnar et al., 2010). These changes in consumer behaviour create a desire for experiences rather than services (Pine and Gilmore, 1998, 2011). The consumer has a central role, passing from being just a buyer to co-producer. In this way, tourism planning needs to consider the importance of creating experiences for consumers, and that these, being a result of the co-creation between supply and demand, can not be completely controlled by the supply, but it can create the conditions necessary for it (Andersson, 2007).

Thus, given the dimensions of the consumer experience in hotels, it is noted that studies that focus specifically on the accommodation experience are still scarce. Walls et al. (2011) identified that hotel experiences were a combination of the physical environment, which includes the environment, space, sensations, symbols, and human interactions, with staff members as well as with other guests. These dimensions influence the guest experience and, therefore, should be considered by hotel managers.

The tourism sector has been growing steadily and is expected to continue growing, being therefore important long-term planning, considering the development of the sector. In this context, UNWTO (2002) identified eleven areas that will affect tourism by 2020 , which, according to Dwyer et al. (2008), are related to each other, being able to be united into five megatrends that act in the macroenvironment: economic, political, social, environmental and technological. These megatrends will influence the decision-making process of tourists, which, in turn, leads the supply side to pay attention to the creation of new products and more efficient management.

Globalization is one of the main factors influencing tourism. Greater ease for tourists to cross borders results in a greater number of international tourists, as well as greater competition between destinations. In this regard, it should be highlighted the growth of international arrivals in emerging economies, namely the Asia and Pacific region, which is projected to grow to 535 million arrivals in 2030, and the emergence of the Chinese market as the largest outbound market in the world (UNWTO, 2011). Demographic changes are pointed out as one of the main areas to influence the tourism sector (Dwyer et al., 2008). Greater life expectancy, coupled with a higher quality of life, means that the world's population is aging and, therefore, the senior population becomes an important segment for the tourist market (Berkup, 2014; Bolton et al., 2013). It is also worth noting the importance that has been attributed to the study of the different generations, and the tourism area has given special attention to generation Y, also known as millenials, since analyzing the behavior of this generation today can help to predict how individuals will behave in the future (Bolton et al., 2013). Political trends can produce positive as well as negative impacts on tourism. Given that the development of tourism requires the existence of a peaceful and non-violent climate, terrorist attacks 
ToSEE - Tourism in Southern and Eastern Europe, Vol. 5, pp. 139-162, 2019

Z. Breda, C. Pacheco, G. Dinis: FUTURE TRENDS IN THE HOSPITALITY INDUSTRY: AN ...

have negative repercussions in tourism, leading to a decrease in the number of reservations, resulting in large monetary losses for the sector (Araña and León, 2008). Regarding environmental trends, climate change is seen as a matter of extreme importance, since tourism is influenced by climate and its changes, and natural disasters (Buckley et al., 2015). In addition, resource depletion, such as petroleum, also makes the sector vulnerable to price fluctuations. Technology-wise, the society is considered to be digital, having a greater need for faster and more innovative technologies (Yeoman, 2012), which means that the tourism sector has to adapt to these needs. There are also new communication and marketing channels that allow more direct contact between consumers and suppliers, with tourists having more control in the processes. These changes in different areas, causing impacts on the tourism system, also affect the hotel industry. The main developments aimed at hotels are automatic check-in, personalization, and individualization with an experience built together with guests and adapted to them, sustainability and technology (Kang et al., 2012; Yeoman, 2012; Lopez et al., 2013; Peiró-Signes et al., 2014; Neuhofer et al., 2015).

\section{METHODOLOGY}

\subsection{Data collection}

Since there was no secondary data available to fulfill the objectives of the study, it was necessary to collect primary data. The target population of the study was all guests who had stayed at least one night in Portuguese hotels in the previous two years. The twoyear time limit has been defined because it has been used in other studies (Callan and Bowman, 2000) and because more than two years might be too long for guests to fully remember all aspects that were addressed in the questionnaire. Limiting the study to hotel establishments is due to the fact that other forms of accommodation have distinct features and, therefore, make it difficult to cover all aspects of different types of accommodation. A non-probabilistic (convenience) sampling was adopted, being therefore not representative of the study population.

The technique chosen for the data collection was the questionnaire, which is the most frequently used in the reviewed literature (Ananth et al., 1992; Callan and Bowman, 2000; Poon and Lock-Teng Low, 2005; Yavas and Babakus, 2003), and one of the most frequently used techniques in tourism and leisure research (Jennings, 2010; Veal, 2006). Most of the questions were closed, with open-ended questions being used only when more detailed information was sought. For most of the closed-ended questions, a 5-point Likert scale was used.

The construction of the questionnaire was based on the literature in order to identify the main questions that could be asked in order to respond to the proposed research objectives. The questionnaire was developed in a way that follows the logic of the decision-making process. In this way, initially it has a general section about what type of hotels the consumer has most used in the previous two years, and what motivations have most often led to their stay. The second part relates to issues concerning the planning process (Gronflaten, 2009; Jun et al., 2010; Sparks and Browning, 2011; Toh et al., 2011; Vermeulen and Seegers, 2009; Xiang et al., 2014; Xiang and Gretzel, 2010), 
ToSEE - Tourism in Southern and Eastern Europe, Vol. 5, pp. 139-162, 2019

Z. Breda, C. Pacheco, G. Dinis: FUTURE TRENDS IN THE HOSPITALITY INDUSTRY: AN ...

reservation (Crnojevac et al., 2010; Dolnicar and Otter, 2003; Lockyer, 2005; Murphy et al., 2016; Toh et al., 2011), satisfaction (Ananth et al., 1992; Atkinson, 1988; Chen, 2014; Chu and Choi, 2000; Dolnicar and Otter, 2003; Saleh and Ryan, 1992; Yavas and Babakus, 2003), recommendation (Lopes, 2015; Serra Cantallops and Salvi, 2014; Yen and Tang, 2015), and perspectives on what the consumer considers to be the future of hotels (Amadeus, 2010; Lopez et al., 2013; Yeoman, 2006, 2012). The questionnaire ends with a section related to the sociodemographic profile of the respondent.

The questionnaire was subjected to a pre-test, in order to identify shortcomings and possible improvements. As a result, small amendments were made, and a question was rewritten in order to make it clearer. It was, then, applied online, in Portuguese and English. The application of online questionnaires has gained popularity, being increasingly used (Hair et al., 2003; Veal, 2006).

In order to obtain answers, 78 emails were sent to Portuguese hotels, as well as to associations of the sector, such as the Portuguese Hotel Association (AHP) and the Portuguese Association of Hospitality, Catering and Associated Industries (AHRESP). Regional tourism boards were also contacted in order to collaborate in the dissemination of the questionnaire. Given that, as a result, only four responses were obtained from this strategy, mentioning that it was not possible to collaborate, the questionnaire was disseminated through social media, namely in Facebook and LinkedIn groups, and by email. The questionnaire was available online from January to March 2016. In this period, 435 complete answers were obtained, of which only 305 were considered valid.

\subsection{Data analysis}

After the application of the questionnaire, the analysis of the collected data was performed through the SPSS software (Statistical Package for the Social Sciences) version 23.0. Univariate analysis was performed, such as frequency distribution, measures of central tendency and dispersion; bivariate analysis with the t-test and the one-way ANOVA test; and multivariate analysis, with Principal Component Analysis (PCA).

For the analysis of the open-ended question, given its qualitative nature, data were organized in a more systematic way, reducing the initial information in smaller information groups with more homogeneous themes. The content analysis followed the steps suggested by Creswell (2009), namely with the preparation and organization of the data, followed by the identification of the main categories. To identify them, a deductive process was followed, based on the categories identified in the literature review, and later inductive, being the categories adapted according to the obtained data. After this phase, it was necessary to codify the answers according to the defined categories and to compare the different cases, analyzing differences and similarities between them, and finally interpreting the results. 
ToSEE - Tourism in Southern and Eastern Europe, Vol. 5, pp. 139-162, 2019

Z. Breda, C. Pacheco, G. Dinis: FUTURE TRENDS IN THE HOSPITALITY INDUSTRY: AN ...

\section{RESULTS}

\subsection{Respondents' profile}

Gender-wise, it is verified that $69.2 \%$ of the respondents are female, while $30.8 \%$ are male (Table 2). The average age of respondents is 32 years old, corresponding this age group, according to Bolton et al. (2013), to the older members of Generation Y, also known as millennials. Respondents are mainly of Portuguese nationality $(92.8 \%)$, followed by Brazilians (2.3\%). In relation to the country of residence, the sample is composed almost exclusively of people living in Portugal (96.1\%). This result differs from the reality of Portuguese hotels, where the number of foreign guests exceeds those of Portuguese. This may be partly justified by the fact that the questionnaire was disseminated in social media and by email, where, despite reaching different nationalities, Portuguese were the ones that most easily had access to the survey.

Table 2: Sociodemographic profile of respondents: gender, age, and country of residence

\begin{tabular}{|l|c|c|c|c|}
\hline & Number & Percentage & Mean & $\begin{array}{c}\text { Standard } \\
\text { deviation }\end{array}$ \\
\hline Gender & & & & \\
\hline Feminine & $\mathbf{2 1 1}$ & $\mathbf{6 9 . 2}$ & & \\
\hline Masculine & 94 & 30.8 & & \\
\hline Age & & & & \\
\hline & & & $\mathbf{3 1 . 7 9}$ & 11.343 \\
\hline Country of residence & & & & \\
\hline Portugal & $\mathbf{2 9 3}$ & $\mathbf{9 6 . 1}$ & & \\
\hline Germany & 3 & 1 & & \\
\hline Brazil & 3 & 1 & & \\
\hline United Kingdom & 2 & 0.7 & & \\
\hline Spain & 1 & 0.3 & & \\
\hline Italy & 1 & 0.3 & & \\
\hline Switzerland & 1 & 0.3 & & \\
\hline USA & 1 & 0.3 & & \\
\hline Total & 305 & 100 & & \\
\hline
\end{tabular}

Source: Own elaboration

Table 3 shows a summary of the educational level, professional status and income of the sample. Most of the respondents have higher education (79\%) and are mostly employed $(48.9 \%)$. In the professional situation, it is also worth mentioning the category 'student' that emerges in second place (29.8\%). Regarding the average monthly net income, $34.1 \%$ of the respondents earn between $€ 505$ and $€ 1,000$, and the 'not applicable' option was the second most expressive with $31.1 \%$, which can be related to the high number of students. 
ToSEE - Tourism in Southern and Eastern Europe, Vol. 5, pp. 139-162, 2019

Z. Breda, C. Pacheco, G. Dinis: FUTURE TRENDS IN THE HOSPITALITY INDUSTRY: AN ...

Table 3: Sociodemographic profile of respondents: education, work situation, and income

\begin{tabular}{|l|l|c|}
\hline \multirow{4}{*}{ Educational level } & \multicolumn{1}{|c|}{ Category } & \% \\
\hline \multirow{5}{*}{ Work situation } & Until the 3rd cycle (9th grade) & 2.3 \\
\cline { 2 - 3 } & Secondary education & 18.7 \\
\cline { 2 - 3 } & Higher education & $\mathbf{7 9 . 0}$ \\
\hline \multirow{5}{*}{ Income } & Unemployed & 4.6 \\
\cline { 2 - 3 } & Employee & $\mathbf{4 8 . 9}$ \\
\cline { 2 - 3 } & Self employed & 11.5 \\
\cline { 2 - 3 } & Employer & 0.7 \\
\cline { 2 - 3 } & Student & 29.8 \\
\cline { 2 - 3 } & Other & 3.3 \\
\cline { 2 - 3 } & Retired & 1.3 \\
\hline \multirow{5}{*}{} & $>2000 €$ & 7.9 \\
\cline { 2 - 3 } & $1501-2000 €$ & 10.5 \\
\cline { 2 - 3 } & $1001-1500 €$ & $\mathbf{3 4 . 1}$ \\
\cline { 2 - 3 } & $\mathbf{5 0 5 € - 1 0 0 0 €}$ & 31.1 \\
\cline { 2 - 3 } & Not applicable & \multicolumn{1}{|c|}{} \\
\hline
\end{tabular}

Source: Own elaboration

Regarding the behavior of the respondents in relation to hotel establishments in the previous two years (Table 4), the majority stated that they have opted for hotels $(75.4 \%)$, specifically 4-star (52.8\%) and 3-star hotels (36.1\%). This result is in line with the official statistics, with the highest number of overnight stays in hotels in these categories. The main purpose of the trip is mostly leisure/vacation/recreation $(82.6 \%)$, followed by business / professional reasons with $14.1 \%$. In terms of average length of stay, it is observed that $27.5 \%$ of the respondents mention that they stay on average 2 nights in hotels, and that overnight stays between 3 and 4 nights recorded $26.2 \%$ of the total sample. These numbers are related to the general panorama of the hotel industry in Portugal, where the average overnight stay is 2.35 nights (INE, 2018).

Table 4: Consumer behavior in hotels in the previous two years

\begin{tabular}{|l|l|c|}
\hline \multirow{1}{*}{$\begin{array}{c}\text { Type of } \\
\text { establishment }\end{array}$} & \multicolumn{1}{|c|}{ Category } & \% \\
\hline \multirow{5}{*}{ Classification } & Hotel & $\mathbf{7 5 . 4}$ \\
\cline { 2 - 3 } & Apartment hotel & 14.1 \\
\cline { 2 - 3 } & Inn & 10.5 \\
\cline { 2 - 3 } & 1-star & 0.7 \\
\cline { 2 - 3 } & 2-star & 4.6 \\
\cline { 2 - 3 } Main reason for & 3-star & 36.1 \\
\cline { 2 - 3 } & 4-star & $\mathbf{5 2 . 8}$ \\
\cline { 2 - 3 } & 5-star & 5.9 \\
\hline \multirow{5}{*}{\begin{tabular}{l} 
overnight stays \\
\cline { 2 - 3 }
\end{tabular}} & Leisure / vacation / recreation & $\mathbf{8 2 . 6}$ \\
\cline { 2 - 3 } & Health reasons / Medical treatments & 0.3 \\
\cline { 2 - 3 } & Religious motives / Pilgrimages & 0.3 \\
\cline { 2 - 3 } & Business / professional reasons & 14.1 \\
\cline { 2 - 3 } & Visiting friends and relatives & 1.0 \\
\cline { 2 - 3 } & Others & 1.6 \\
\hline
\end{tabular}


ToSEE - Tourism in Southern and Eastern Europe, Vol. 5, pp. 139-162, 2019

Z. Breda, C. Pacheco, G. Dinis: FUTURE TRENDS IN THE HOSPITALITY INDUSTRY: AN ...

\begin{tabular}{|c|c|c|}
\hline & Category & $\%$ \\
\hline \multirow{5}{*}{$\begin{array}{l}\text { Average length of } \\
\text { stay }\end{array}$} & 1 night & 10.5 \\
\hline & 2 nights & 27.5 \\
\hline & 3 to 4 nights & 26.2 \\
\hline & 5 to 8 nights & 19.0 \\
\hline & More than 8 nights & 16.7 \\
\hline
\end{tabular}

Source: Own elaboration

\subsection{Behavior in relation to accommodation planning}

Respondents used a 5-point scale ( $1=$ not important / $5=$ very important $)$ to identify the most important sources of information. Table 5 reveals that past experiences appear as the most important source (4.32), followed by customer review sites (4.25) and websites of the hotels (4.12). Consumers first use internal sources - their past experiences - and then external sources, with the Internet being the most relevant one, especially review and hotel websites, thus corroborating the literature, which indicates that the search for consumer information begins in memories (Fodness and Murray, 1999; Chen and Gursoy, 2000) and later on external sources, being the Internet the main external source (Toh et al., 2011; Xiang et al., 2014). In addition, there is a considerable number of respondents $(31 \%)$ that do not use travel agencies as a source of information, and their importance by those who use them is not very high (2.95).

\section{Table 5: Importance of information sources}

\begin{tabular}{|l|c|c|c|}
\hline & Use & Mean & $\begin{array}{c}\text { Standard } \\
\text { deviation }\end{array}$ \\
\hline $\begin{array}{l}\text { Brochures and catalogues / Travel guides / } \\
\text { Travel magazines }\end{array}$ & $76 \%$ & 3.28 & 1.164 \\
\hline Travel agencies & $69 \%$ & 2.95 & 1.214 \\
\hline Feedback from friends and / or relatives & $97 \%$ & 3.95 & 0.941 \\
\hline Past experiences & $99 \%$ & $\mathbf{4 . 3 2}$ & 0.810 \\
\hline Website of hotel establishments & $98 \%$ & $\mathbf{4 . 1 2}$ & 0.837 \\
\hline Blogs & $77 \%$ & 3.17 & 1.117 \\
\hline $\begin{array}{l}\text { Social networks (e.g. Facebook / Twitter / } \\
\text { Instagram) }\end{array}$ & $90 \%$ & 3.42 & 1.108 \\
\hline $\begin{array}{l}\text { Customer review sites (e.g. Tripadvisor / } \\
\text { Booking) }\end{array}$ & $97 \%$ & $\mathbf{4 . 2 5}$ & 0.879 \\
\hline Data sharing sites (e.g. Youtube / Flickr) & $70 \%$ & 2.92 & 1.086 \\
\hline
\end{tabular}

Source: Own elaboration

Although the literature indicates that personal factors influence the way in which consumers search for information about hotels (Beldona and Cobanoglu, 2007; Hernández et al., 2011), there is no evidence of relationships between sociodemographic variables (age and educational qualifications) and sources of information ( $\alpha=0,251$ and $\alpha=0,424$, respectively). Nevertheless, Gronflaten (2009) points out that the results are not always consistent, for example, one study points out that travel agents are more important for the age group over 50 and another study concludes that they are not important for this age group. 
ToSEE - Tourism in Southern and Eastern Europe, Vol. 5, pp. 139-162, 2019

Z. Breda, C. Pacheco, G. Dinis: FUTURE TRENDS IN THE HOSPITALITY INDUSTRY: AN

The Internet is also the main reservation channel for hotel establishments $(55.7 \%)$, followed by direct contact with the hotels $(33.8 \%)$ and travel agencies $(9.2 \%)$. Although the Internet is not pointed out in the literature as the main reservation channel, it has been observed growth of online sales, with forecasts showing its continuous growth (Euromonitor, 2014). Respondents who stated that they prefer to make the reservation directly with the hotel do it mainly through e-mail (42\%) or telephone (41\%). Only $9 \%$ of respondents make the reservation directly on the hotels' website. Reservations made through travel agencies are usually done personally at the agency (8\%). Reservations on the Internet are mainly done on Booking.com (87.65\%), with only 3\% referring to Hotels.com, and $9 \%$ reported using other websites.

\subsection{Determinants of hotel choice and guest satisfaction}

Yavas and Babakus (2003) argue that there is scarce research to assess the difference between the importance attributed by the consumer and the performance of the hotel. Given the importance of knowing which attributes consumers value and the performance of the hotel in relation to them (Wilkins, 2010), respondents evaluated, in a 5-point scale, the importance and the respective satisfaction for several attributes identified in the literature. A descriptive analysis was performed to obtain the mean of the attributes in each of the parameters (importance/satisfaction), then a t-test was undertaken to identify statistically significant differences between the two means (Table 6).

Table 6: Importance and satisfaction of hotel attributes

\begin{tabular}{|c|c|c|c|c|}
\hline Attributes & Importance & Satisfaction & Difference & p-value \\
\hline $\begin{array}{l}\text { Attractiveness of exterior design / } \\
\text { appearance }\end{array}$ & 3.89 & 3.80 & 0,09 & .085 \\
\hline Attractiveness of interior design & 4.10 & 3.85 & 0,25 & $<0.001$ \\
\hline Good soundproofing of rooms & 3.99 & 3.77 & 0,22 & $<0.001$ \\
\hline Flexible check-in / check-out & 3.90 & 3.75 & 0,15 & .016 \\
\hline Comfort of room / bed & 4.47 & 4.15 & 0,32 & $<0.001$ \\
\hline Fitness center / gym & 2.36 & 2.76 & $-0,4$ & $<0.001$ \\
\hline Entertainment areas & 2.99 & 3.07 & $-0,08$ & .207 \\
\hline Existence of air conditioning & 3.93 & 3.95 & $-0,02$ & .710 \\
\hline Breakfast included & 4.49 & 4.25 & 0,24 & $<0.001$ \\
\hline Easiness of making reservations & 4.29 & 4.11 & 0,18 & $<0.001$ \\
\hline Room facilities & 3.48 & 3.49 & $-0,01$ & .904 \\
\hline Cleanliness of rooms and bathrooms & 4.77 & 4.34 & 0,43 & $<0.001$ \\
\hline Cleanliness of common areas & 4.51 & 4.21 & 0,3 & $<0.001$ \\
\hline Convenient location & 4.30 & 4.10 & 0,2 & $<0.001$ \\
\hline Swimming pool & 3.33 & 3.44 & $-0,11$ & .080 \\
\hline Price & 4.57 & 4.03 & 0,54 & $<0.001$ \\
\hline Professionalism of staff & 4.44 & 4.05 & 0,39 & $<0.001$ \\
\hline $\begin{array}{l}\text { Possibility to customize services / } \\
\text { room }\end{array}$ & 2.95 & 2.99 & $-0,04$ & .565 \\
\hline Quality of food / drinks & 4.08 & 3.81 & 0,27 & $<0.001$ \\
\hline Hotel / hotel brand reputation & 3.56 & 3.58 & $-0,02$ & .821 \\
\hline Meeting room / Business center & 1.87 & 2.44 & $-0,57$ & $<0.001$ \\
\hline Safety & 4.32 & 4.15 & 0,17 & $<0.001$ \\
\hline
\end{tabular}


ToSEE - Tourism in Southern and Eastern Europe, Vol. 5, pp. 139-162, 2019

Z. Breda, C. Pacheco, G. Dinis: FUTURE TRENDS IN THE HOSPITALITY INDUSTRY: AN ...

\begin{tabular}{|l|c|c|c|c|}
\hline Attributes & Importance & Satisfaction & Difference & p-value \\
\hline Telephone service & 2.34 & 2.90 & $-0,56$ & $<\mathbf{0 . 0 0 1}$ \\
\hline 24-hour room service & 2.77 & 3.11 & $-0,34$ & $<\mathbf{0 . 0 0 1}$ \\
\hline Cable TV & 3.31 & 3.43 & $-0,12$ & .090 \\
\hline $\begin{array}{l}\text { Use of technology (e.g. free wi-fi / } \\
\text { tablets available) }\end{array}$ & 4.05 & 3.56 & 0,49 & $<0.001$ \\
\hline $\begin{array}{l}\text { Use of sustainable practices / hotel } \\
\text { sustainability }\end{array}$ & 3.72 & 3.40 & 0,32 & $<\mathbf{0 . 0 0 1}$ \\
\hline
\end{tabular}

Source: Own elaboration

Respondents considered cleanliness of the rooms and bathrooms, price, cleanliness of common areas, included breakfast, comfort of the room/bed, professionalism of the services, security, location and easiness in making reservations as the most important attributes, with averages between 4.29 and 4.77. This result is consistent with that of Yavas and Babakus (2003), who found that, for leisure travelers, cleanliness of rooms and bathrooms was the most important attribute. Also, price, service readiness, security, and location are usually pointed out in the literature as the most important ones (Ananth et al., 1992; Barsky, 1992; Wilensky and Buttle, 1988; Yavas and Babakus, 2003). The results highlight the importance attached to the existence of breakfast included and the easiness of making reservations, which are not so frequently reported in the literature. On the other hand, results also show the weak importance given to the reputation of the hotel/hotel brand, which is the most frequently mentioned attribute (Choi and Chu, 2001; Dolnicar and Otter, 2003).

In most attributes, satisfaction fell below importance, which may indicate that the expectations of the consumers are not being met by the attributes' performance. The use of technology and price are in this group, which are highlighted by the low satisfaction of respondents. In the case of technology, Beldona and Cobanoglu (2007) refer that the hotel industry is being slow in its adoption and may, therefore, explain these results. There are differences in attributes, such as meeting room, telephone service, fitness equipment and area, and 24-hour room service, which have obtained greater satisfaction scores compared to importance, therefore should not be considered strong points of hotel establishments.

In order to synthesize the information, a PCA was carried out to determine the determinant attributes for hotel choice. Using the varimax orthogonal rotation method, in order to maximize the loadings values and to ensure that each variable was associated with only one factor, seven factors were obtained (Table 7). The results of the PCA analysis reveal that the factorial analysis is good, and, except for one item, the commonalities are greater than 0.5 and the value of KMO is 0.818 . The Barletts test has a significance level of 0.00 and the cumulative explained percentage is 63.9. As for Cronbach's Alpha values, these are higher than 0.6 in five of the factors, the other two presenting values of 0.451 and 0.459 , including only two items in each. Even though the value is low, according to Schmitt (1996, p. 353), "there is no sacred level of acceptable or unacceptable level of alpha. In some cases, measures with (by conventional standards) low levels of alpha may still be quite useful". 
ToSEE - Tourism in Southern and Eastern Europe, Vol. 5, pp. 139-162, 2019

Z. Breda, C. Pacheco, G. Dinis: FUTURE TRENDS IN THE HOSPITALITY INDUSTRY: AN ...

The factors were denominated by Factor 1: 'Quality of service', which includes variables related to cleanliness, staff professionalism and comfort; Factor 2: 'Complementary services', which relates to room service, telephone, flexibility of check-in / out and meeting room; Factor 3: 'Leisure and recreation', including variables such as swimming pool, gymnasium and entertainment areas; Factor 4: 'Food and beverage', which groups the variables related to restaurant and food quality; Factor 5: 'Design attractiveness', which includes the two variables related to the attractiveness of interior and exterior design; Factor 6: 'Price and location'; and Factor 7: 'Technology and sustainability'. Considering the average of the factors, the 'Quality of Service' factor has the highest average (4.503), and this factor can be considered the most important for the consumers, followed by the 'Price and location' (4.436).

Table 7: PCA of the determining attributes for hotel choice

\begin{tabular}{|c|c|c|c|c|c|c|c|c|c|}
\hline Attributes & $\begin{array}{l}\text { Commu- } \\
\text { nalities }\end{array}$ & Mean & F1 & F2 & F3 & F4 & F5 & F6 & F7 \\
\hline $\begin{array}{l}\text { Cleanliness of } \\
\text { rooms and } \\
\text { bathrooms }\end{array}$ & .761 & \multirow{5}{*}{4.503} & .841 & & & & & & \\
\hline $\begin{array}{l}\text { Cleanliness of } \\
\text { common areas }\end{array}$ & .734 & & .813 & & & & & & \\
\hline Security & .525 & & .617 & & & & & & \\
\hline $\begin{array}{l}\text { Professionalism } \\
\text { of staff }\end{array}$ & .608 & & .597 & & & & & & \\
\hline $\begin{array}{l}\text { Comfort of room } \\
\text { / bed }\end{array}$ & .574 & & .414 & & & & & & \\
\hline $\begin{array}{l}\text { 24-hour room } \\
\text { service }\end{array}$ & .641 & \multirow{4}{*}{2.720} & & .755 & & & & & \\
\hline $\begin{array}{l}\text { Telephone } \\
\text { service }\end{array}$ & .650 & & & .733 & & & & & \\
\hline $\begin{array}{l}\text { Meeting room / } \\
\text { Business center }\end{array}$ & .620 & & & .728 & & & & & \\
\hline $\begin{array}{l}\text { Flexible check- } \\
\text { in / check-out }\end{array}$ & .599 & & & .545 & & & & & \\
\hline Swimming pool & .598 & \multirow{3}{*}{2.892} & & & .753 & & & & \\
\hline $\begin{array}{l}\text { Entertainment } \\
\text { areas }\end{array}$ & .650 & & & & .733 & & & & \\
\hline $\begin{array}{l}\text { Fitness center / } \\
\text { gym }\end{array}$ & .573 & & & & .647 & & & & \\
\hline $\begin{array}{l}\text { Breakfast } \\
\text { included }\end{array}$ & .699 & \multirow{4}{*}{3.993} & & & & .791 & & & \\
\hline Restaurant & .625 & & & & & .638 & & & \\
\hline $\begin{array}{l}\text { Quality of food / } \\
\text { drinks }\end{array}$ & .689 & & & & & .553 & & & \\
\hline $\begin{array}{l}\text { Existence of air } \\
\text { conditioning }\end{array}$ & .494 & & & & & .446 & & & \\
\hline $\begin{array}{l}\text { Attractiveness of } \\
\text { interior design / } \\
\text { appearance }\end{array}$ & .753 & \multirow[t]{2}{*}{3.993} & & & & & .827 & & \\
\hline $\begin{array}{l}\text { Attractiveness of } \\
\text { exterior design }\end{array}$ & .729 & & & & & & .801 & & \\
\hline $\begin{array}{l}\text { Convenient } \\
\text { location }\end{array}$ & .682 & \multirow[t]{2}{*}{4.436} & & & & & & .815 & \\
\hline Price & .598 & & & & & & & .737 & \\
\hline
\end{tabular}


ToSEE - Tourism in Southern and Eastern Europe, Vol. 5, pp. 139-162, 2019

Z. Breda, C. Pacheco, G. Dinis: FUTURE TRENDS IN THE HOSPITALITY INDUSTRY: AN ...

\begin{tabular}{|c|c|c|c|c|c|c|c|c|c|}
\hline Attributes & $\begin{array}{l}\text { Commu- } \\
\text { nalities }\end{array}$ & Mean & F1 & F2 & F3 & F4 & F5 & F6 & F7 \\
\hline $\begin{array}{l}\text { Use of } \\
\text { technology }\end{array}$ & .785 & \multirow[b]{2}{*}{3.888} & & & & & & & .858 \\
\hline $\begin{array}{l}\text { Use of } \\
\text { sustainable } \\
\text { practices }\end{array}$ & .590 & & & & & & & & .527 \\
\hline \multicolumn{2}{|l|}{ Own values } & & 5.570 & 2.238 & 1.733 & 1.290 & 1.187 & 1.053 & 1.005 \\
\hline \multicolumn{2}{|c|}{$\begin{array}{l}\text { Explained cumulative } \\
\text { variance }(\%)\end{array}$} & & 25.318 & 35.489 & 43.365 & 49.230 & 54.627 & 59.414 & 63.983 \\
\hline \multicolumn{2}{|c|}{ Cronbach's Alpha } & & .791 & .726 & .697 & .671 & .756 & .451 & .459 \\
\hline
\end{tabular}

Source: Own elaboration

\subsection{Recommendation}

After their experience in hotels, $53.4 \%$ of respondents state that they do not write online reviews, with only $15.4 \%$ doing so regularly and $31.1 \%$ from time to time. This data reveals that, although customer review sites are considered one of the most important sources of information in the planning stage, most respondents do not use them to share their experience. Through the one-way analysis of variance (ANOVA) it was possible to verify that there are statistically significant differences between the use of this source of information and consumers' eWOM production (Table 8). Respondents who produced eWOM were asked about what motivated them to write online reviews, on a 5-point Likert scale $(1=$ do not agree $/ 5=$ totally agree $)$. Table 7 shows that their main motivation is to reciprocate, as they also seek online reviews while choosing hotels (4.42). In addition, sharing service satisfaction (4.15) and helping others (4.01) is also evident. These results are in line with those obtained by Lopes (2015), who concludes that consumers feel they should write reviews because they also seek advice from others, and by Serra Cantallops and Salvi (2014), who report that one of the main motivations for eWOM are social benefits and altruism.

Table 8: Motivations for eWOM production

\begin{tabular}{|c|c|c|}
\hline & Mean & $\begin{array}{l}\text { Standard } \\
\text { deviation }\end{array}$ \\
\hline I like to share information about my personal experiences. & 3.78 & 1.244 \\
\hline $\begin{array}{l}\text { I enjoy sharing information about my travel experiences with } \\
\text { different Internet users. }\end{array}$ & 3.46 & 1.236 \\
\hline I also search online for advice on choosing hotels. & 4.42 & .801 \\
\hline I feel like I belong to a community. & 2.61 & 1.197 \\
\hline I want to share my dissatisfaction. & 3.45 & 1.345 \\
\hline I want to share my satisfaction / quality of service. & 4.15 & .891 \\
\hline I want to help the hotel establishment where I stayed. & 3.88 & 1.120 \\
\hline I like the feeling of helping others. & 4.01 & 1.062 \\
\hline
\end{tabular}

Source: Own elaboration 
ToSEE - Tourism in Southern and Eastern Europe, Vol. 5, pp. 139-162, 2019

Z. Breda, C. Pacheco, G. Dinis: FUTURE TRENDS IN THE HOSPITALITY INDUSTRY: AN ...

\subsection{Trends}

In order to identify the expectations and needs of the guests, an open question was inserted in the questionnaire and, therefore, it was analyzed through content analysis, having 18 categories been created (Table 9).

\section{Table 9: Frequencies the categories of content analysis}

\begin{tabular}{|l|c|}
\hline \multicolumn{1}{|c|}{ Categories } & No. \\
\hline Customization & 67 \\
\hline Technology (in general) & 51 \\
\hline Digital room key or through facial recognition & 44 \\
\hline Competent staff/professionals/customer proximity & 34 \\
\hline Accommodation experience/integrate the hotel with the destination & 25 \\
\hline Know guests' tastes through social networks/apps & 21 \\
\hline Sustainability & 20 \\
\hline Easier and more flexible check-in/out & 12 \\
\hline Quality of service/cleanliness/rooms & 12 \\
\hline Free wi-fi & 10 \\
\hline Price & 9 \\
\hline More varied meals & 6 \\
\hline Allow pets & 4 \\
\hline Privacy & 3 \\
\hline I do not know / I do not answer & 9 \\
\hline
\end{tabular}

Source: Own elaboration

"Personalization" was the most mentioned category, corroborating the literature, which indicates personalization and individualization as an essential aspect for the future of the hotel industry (Amadeus, 2010; Yeoman, 2012). Respondents stated that they wanted a more individualized service that suited their tastes and needs, referring, for example, to "an increasingly personalized and attentive service, motivating guests to return. In future visits [hotels should] build on previous stays to pleasantely surprise their customers through details and emotions" (I 105). The use of surveys at check-in or the creation of databases are referred to as ways for the hotel to be prepared for greater personalization, such as adjusting rooms to personal tastes, as one respondent states: "Hotels should have a database of each client that would keep [the information on] their orders or the meals they mostly eat and what food is preferred, as well as other aspects that distinguish each guest and their choices and tastes" (I 48).

Personalization comes alongside technology (Neuhofer et al., 2015), and this is also visible in the results, with 'digital room key or through face recognition' and 'technology' emerging as important categories. Ease and safety are the most important reasons to change the traditional room keys to a more technological solution: "I think that opening the room through digital recognition would also be an added advantage as the guest would have no worries about keeping and not losing a physical key" (I 79). Consumers expect a greater implementation and enjoyment of technology for a higher quality of the guest experience: "Technology is increasingly advancing and in constant 
ToSEE - Tourism in Southern and Eastern Europe, Vol. 5, pp. 139-162, 2019

Z. Breda, C. Pacheco, G. Dinis: FUTURE TRENDS IN THE HOSPITALITY INDUSTRY: AN ...

innovation, I look forward that in the hotel industry technology is ever closer, always thinking about customers' well-being and satisfaction" (I 271). In general terms, consumers expect technology to streamline and facilitate processes, such as their use for light and temperature control systems, stressing that it should focus on consumer satisfaction: "It is necessary to follow the technological evolution and use strategies that facilitate hotel procedures (reservation, check-in, room service, hotel dynamics, etc.) focused on its customers" (I 205). It is noteworthy that many respondents stated that, even wanting more technological solutions, they did not intend to see the human part of the hotel neglected.

Consumers believe that the future of hotels also goes hand in hand with staff empathy and professionalism: "It is enough that the staff is attentive and empathetic with the guests. Professionalism is what leads me to choose a hotel" (I 152); "I think more and more what makes a hotel are the employees/staff. A bad hotel can provide a great experience if the staff is available, friendly, informed and friendly, and an excellent hotel can be a place not to return again if the staff is indifferent, frowning" (I 102).

The hotel experience/integrating the hotel with the destination is identified by 25 of the consumers, who mention the need for the hotel to become an experience itself. It was often mentioned that a commitment should be made to their integration with local communities, creating more partnerships with stakeholders, offering guests a range of activities and services: "to create an experience, greater integration with other services: transport, entertainment and food" (I 27); "I hope that, in the future, hotels will [...] offer something more cultural that gives us an opportunity to participate" (I 18). This desire for experience is corroborated by Oh et al. (2007), who point out that tourism essentially sells experiences, with consumers having the desire and need to consume experiences and not just products or services (Pine and Gilmore, 2011). The Portuguese hotel establishments should, therefore, focus on creating more value for customers by providing them with a more complete and immersive accommodation experience, integrating more the hotel in the destination and making it easier for the guest to have access to entertainment opportunities and activities outside the hotel.

The 'know my tastes through social networks/apps' category was mentioned by 21 respondents. This can also be related to 'personalization' and 'technology', differing by the fact that respondents clearly indicated that they want their tastes to be collected through social media or apps, distinguishing themselves from others who also expect the hotel to personalize their stay but prefer it through other means. Familiarity with technology by generations $\mathrm{Y}$ and $\mathrm{X}$ brings new expectations (Yeoman, 2012), and social media gains importance as a platform for hotels, serving not only to attract customers but also to meet their wishes and make their experience more personalized.

Sustainability, which in the literature emerges as having growing importance for hotel choice (Chen, 2014; Yeoman, 2012), also arises in the data analysis, referred to by 20 respondents as an issue to be considered in the future of the hotel industry. Consumer expectations are essentially related to the implementation of sustainable practices, such as new ways of saving energy or water: "I would like to see environmental sustainability actions more clearly and visibly (not just the towels)" (I 9); "The energy used will come 
ToSEE - Tourism in Southern and Eastern Europe, Vol. 5, pp. 139-162, 2019

Z. Breda, C. Pacheco, G. Dinis: FUTURE TRENDS IN THE HOSPITALITY INDUSTRY: AN

exclusively from renewable sources (Green Energy Tourism). The windows and all exterior windows will be able to capture and store energy" (I 6).

For 12 respondents, the future of hospitality should lead to faster and more flexible check-in / out, and Amadeus (2010) believes that this is also one of the main developments that will happen in the future. Consumers express a desire for greater flexibility in the time of check-in and check-out, and that the process is not time consuming, suggesting the use of technology to facilitate the whole process: "In the future I would like to check in automatically by quickly reading a reservation card or through an app that will have access to the hotel's internal network and will check-in in a few seconds" (I 138).

Quality of the service/infrastructure is mentioned as one of the aspects to be taken into account in the future of the hotel industry, and the respondents revealed that their needs and expectations relate to the offer a quality service, through the comfort of the rooms, cleanliness or good maintenance of the infrastructures, noting that these are distinctive characteristics: "More than any innovation, I would always like to see respected the sacred principles of accommodation, from the perspective of the client: hygiene, convenience and conservation of the room and common areas" (I 122); "Cleanliness, comfort, and design is what matters the most to me" (I 214).

As far as the Internet is concerned, the need for it to be free and accessible throughout the hotel is stressed globally, in accordance with Yeoman (2012), who emphasized a greater requirement for connectivity in hotels. The fact that the number of respondents in this category is not very high can also mean that they already take this service for granted and not necessarily an expectation about the future, as highlighted by Muller (2010).

More affordable prices, more varied meals, emphasizing the inclusion of vegetarian menus and healthier options, the possibility of allowing pets, the need to respect the guest privacy, not using technology in an intrusive way, and the non-collection of information, unless authorized by the guest, represent, in a global way, other needs and expectations expressed by consumers.

\section{CONCLUSION}

Anticipating which products and services will be consumed in the future is an issue that concerns managers, politicians, and academics. To understand the future of tourism is necessary to consider both the trends that are emerging due to changes in the consumer, as well as trends in the external environment. The way in which these are to be managed and anticipated will influence tourism and its future (Costa and Buhalis, 2006b). Understanding and knowing the consumer is key to a successful business in the tourism industry (Goeldner et al. 1995; Middleton and Clarke, 2001), and it is essential to understand the decision-making process for the purchase of tourism products, in order to develop more effective marketing strategies. This process is referred to as having five distinct phases that begin in the pre-experience, with the recognition of a need, and continues to the post-experience, with the evaluation of the trip. The different phases 
ToSEE - Tourism in Southern and Eastern Europe, Vol. 5, pp. 139-162, 2019

Z. Breda, C. Pacheco, G. Dinis: FUTURE TRENDS IN THE HOSPITALITY INDUSTRY: AN ...

interrelate and are influenced by personal, cultural, social or psychological factors (Mathieson and Wall, 1982; Kotler et al., 2011).

The aim of this research was to analyze consumer behavior in Portuguese hotels. For that, an online questionnaire was applied to guests who had stayed at least one night in the previous two years. Results show that the Internet is the most important external source for information, as reported in the literature (Jun et al., 2010), and is also the most used channel for reservation, especially through the Booking.com website.

Regarding the determinant attributes, 'quality of the service', which includes variables such as cleanliness, staff professionalism and comfort, and 'price and location' were considered the most important. It should be noted that the performance of the attributes was, for the most part, lower than their importance, and the meeting room, telephone service, and fitness center/gym were able to overcome their importance, however, were not considered to be very important by the respondents and, therefore, should not be considered strengths of hotel establishments.

The recommendation was focused on the production of eWOM given the growing importance that this topic has gained in the area of tourism (Sparks and Browning, 2011). It is concluded that, although the use of review websites is the main external source for information, most of the respondents do not produce eWOM after their hotel stay. However, the number of respondents who do it on a regular or occasional basis is still considerable, with respondents claiming to share their reviews online because they also sought online reviews to choose the hotel.

In terms of expectations regarding the future of hotels, in line with the literature, personalization, and technology emerged as the most relevant categories for the consumer. The importance of a more consumer-friendly experience is related to the changes that emerge in the consumer and that lead to an experience economy (Pine and Gilmore, 1998). In turn, technology is important for the consumer at the planning, booking and recommendation stages, and it is expected to continue in the future. Consumers expect technology to streamline and facilitate processes, such as its use for light and temperature control systems, emphasizing that it should be focused on consumer satisfaction.

Considering the results obtained in the empirical study, together with the literature review, it is possible to present some recommendations for Portuguese hotel establishments. There should be a growing bet on digital marketing strategies, with a greater online promotion and careful management of different social media platforms and the hotel's own website. The presence on review websites proves essential to understand what image is being transmitted to potential consumers, since it is where they seek advice and information. In addition, on these websites it is possible to respond to customers, namely to their complaints, managing the hotel's online reputation.

As for the reservations, it was possible to verify the importance of Booking.com, which reveals that hotels use online travel agencies to increase their sales, thus working with intermediaries. Direct sales are perceived to be more appealing because they involve 
ToSEE - Tourism in Southern and Eastern Europe, Vol. 5, pp. 139-162, 2019

Z. Breda, C. Pacheco, G. Dinis: FUTURE TRENDS IN THE HOSPITALITY INDUSTRY: AN ...

fewer costs, so efforts can be made to attract consumers to book directly with the hotel, especially through its website, given that consumers make the reservation online.

Considering the analysis of the determining attributes, it is suggested that efforts be made to offer guests a high-quality service, given the importance that attributes such as cleanliness, room comfort and safety have for the consumer, and since these did not perform satisfactorily. Also, it is recommended that each establishment uses the importance-performance analysis, in order to identify its strengths and weaknesses and figure out where to focus its resources. The commitment to staff training, ensuring that it provides a professional and efficient service is also an important point to be considered. Besides being an element capable of influencing the hotel guest experience, consumers feel that the professionalism of the staff is an important attribute, emphasizing the importance of the relationship between employees and clients.

Technology is an element that should be transverse to the guest experience and be used to improve the efficiency of the services or processes. By analyzing consumer expectations, they ambition that technology improves service quality, facilitating some processes, such as the replacement of the room key or card by facial recognition, demonstrating, nevertheless, that hotels should maintain their human touch. Considering also the characteristics of the new generations, in particular millennials, which have higher technology requirements, hotel managers should consider a greater integration of technology in their establishments in order to increase the quality of the guest experience and, consequently, their satisfaction. In addition, it is recommended that hotel establishments not only sell rooms but an experience, since consumers wish to buy more than a service, wishing that the hotel experience is more personalized and attentive to their preferences, and that hotels are more integrated with the local community.

This study has some limitations resulting from constraints that have arisen in the development of this work. One of the difficulties was the delimitation of the field of study. Since this research addresses several topics, a broader approach was necessary for each topic, and a much more in-depth approach would have been possible in each section. Another limitation is related to data collection. Since there was a lack of collaboration of hotel establishments, the questionnaire was disseminated in social networks, conditioning the responses obtained. Being only administered and disseminated online, targeting people who already use the Internet, the results related to the importance and use of the Internet might have been influenced by this. Therefore, it is suggested that in future research the questionnaire would be applied face to face so as to guarantee a greater diversity of respondents. A more complete data analysis could have been performed, using deeper multivariate analysis. There was also a difficulty in finding studies that approached the future of accommodation, especially focused on the consumer perspective, and literature in this area is still scarce. For this reason, a more indepth analysis of this topic is suggested in future studies, possibly using a qualitative methodology, which allows for more in-depth information.

Despite these limitations, the study allowed to synthesize information about consumer behavior regarding hotel establishments, as well as the trends that are influencing tourism. Through the empirical study it was possible to obtain a broad view of how consumers behave in the hotel pre- and post-experience, as well as knowing the attributes 
ToSEE - Tourism in Southern and Eastern Europe, Vol. 5, pp. 139-162, 2019

Z. Breda, C. Pacheco, G. Dinis: FUTURE TRENDS IN THE HOSPITALITY INDUSTRY: AN

that guests consider important for the choice of accommodation, and if they are satisfied with the hotel performance. This analysis helps managers deepen their knowledge about their clients, better understanding how they plan and book their stay, allowing the identification of strengths and weaknesses of the accommodation, useful for understanding where to allocate or withdraw resources.

\section{REFERENCES}

Amadeus. (2010), "Hotels 2020: Beyond segmentation - Strategies for growth in an era of personalization and global change", available at https://amadeus.com/documents/en/hospitality/research-report/hotels 2020-beyond-segmentation.pdf?crt=DownloadRequest

Ananth, M., DeMicco, F.J., Moreo, P.J. and Howey, R.M. (1992), "Marketplace lodging needs of mature travellers", Cornell Hotel and Restaurant Administration Quarterly, Vol. 33, No. 4, pp. 12-24, https://doi.org/10.1108/09596119810240924

Anderson, E., Fornell, C. and Lehmann, D. (1994), "Customer satisfaction, market share, and profitability: Findings from Sweden”, Journal of Marketing, Vol. 58, No. 3, pp. 53-66, http://dx.doi.org/10.2307/1252310

Andersson, T.D. (2007), "The tourist in the experience economy", Scandinavian Journal of Hospitality and Tourism, Vol. 7, No. 1, pp. 46-58, https://doi.org/10.1080/15022250701224035

Araña, J.E. and León, C.J. (2008), "The impact of terrorism on tourism demand", Annals of Tourism Research Vol. 35, No. 2, pp. 299-315, https://doi.org/10.1016/j.annals.2007.08.003

Atkinson, A. (1988), "Answering the eternal questionwhat does the customer want", Cornell Hotel and Restaurant Administration Quarterly, Vol. 29, No. 2, pp. 12-14. http://doi.org/10.1177/001088048802900209

Baloglu, S. and Uysal, M. (1996), "Market segments of push and pull motivations: A canonical correlation approach", International Journal of Contemporary Hospitality Management, Vol. 8, No. 3, pp. 32 38, https://doi.org/10.1108/09596119610115989

Barsky, J. (1992), "A strategy for customer satisfaction", The Cornell Hotel and Restaurant Administration Quarterly, Vol. 33, No. 5, pp. 32-40, https://doi.org/10.1177/004728759303100429

Baumgarten, J.-C. (2006), "Forword", in Costa, C. and Buhalis, D. (Eds.), Tourism management dynamics. Trends, management and tools, Elsevier, pp. xix-xx.

Beldona, S. and Cobanoglu, C. (2007), "Importance-Performance Analysis of guest technologies in the lodging industry", Cornell Hotel and Restaurant Administration Quarterly, Vol. 48, No. 3, pp. 299-312, https://doi.org/10.1177/0010880407304023

Berkup, S. (2014), "Working with generations X and Y in generation Z period: Management of different generations in business life", Mediterranean Journal of Social Sciences, Vol. 5, No. 19, p. 218, https://doi.org/10.5901/mjss.2014.v5n19p218

Bolton, R.N., Parasuraman, A., Hoefnagels, A., Migchels, N., Kabadayi, S., Gruber, T., Loureiro, Y.K. and Solnet, D. (2013), "Understanding generation Y and their use of social media: A review and research agenda", Journal of Service Management, Vol. 24, No. 3, pp. 245-267, https://doi.org/10.1108/09564231311326987

Buckley, R., Gretzel, U., Scott, D., Weaver, D. and Becken, S. (2015), “Tourism megatrends", Tourism Recreation Research, Vol. 40, No 1, 59-70, //doi.org/10.1080/02508281.2015.1005942

Bulchand-Gidumal, J., Melián-González, S. and López-Valcárcel, B.G. (2011), "Improving hotel ratings by offering free Wi-Fi”, Journal of Hospitality and Tourism Technology, Vol. 2, No. 3, pp. 235-245, https://doi.org/10.1108/17579881111173776

Buttle, F. (1991), Hotel and food service marketing: A managerial approach, Holt, Rinehart \& Winston of Canada Ltd.

Cadotte, E.R. and Turgeon, N. (1988), "Key factors in guest satisfaction", Cornell Hotel and Restaurant Administration Quarterly, Vol. 28, No. 4, pp. 44-51, https://doi.org/10.1177/001088048802800415

Callan, R.J. and Bowman, L. (2000), "Selecting a hotel and determining salient quality attributes: A preliminary study of mature british travellers", International Journal of Tourism Research, Vol. 2, No. 2, pp. 97-118, https://doi.org/10.1002/(SICI)1522-1970(200003/04)2:2<97::AID-JTR190>3.0.CO;2-1

Chaves, M.S., Gomes, R. and Pedron, C. (2012), “Analysing reviews in the Web 2.0: Small and medium hotels in Portugal”, Tourism Management, Vol. 33, No. 5, pp. 1286-1287. http://doi.org/10.1016/j.tourman.2011.11.007 
ToSEE - Tourism in Southern and Eastern Europe, Vol. 5, pp. 139-162, 2019

Z. Breda, C. Pacheco, G. Dinis: FUTURE TRENDS IN THE HOSPITALITY INDUSTRY: AN ...

Chen, J.S. (2000), “A comparison of information usage between business and leisure travellers", Journal of Hospitality \& Leisure Marketing, Vol. 7, No. 2, pp. 65-76, https://doi.org/10.1300/J150v07n02_05

Chen, J.S. and Gursoy, D. (2000), "Cross-cultural comparison of the information sources used by first-time and repeat travelers and its marketing implications", International Journal of Hospitality Management, Vol. 19, No. 2, pp. 191-203, https://doi.org/10.1177/109634800002400207

Chen, R.J.C. (2014), "From sustainability to customer loyalty: A case of full service hotels' guests", Journal of Retailing and Consumer Services, Vol. 22, No. 1, pp. 261-265, https://doi.org/10.1016/j.jretconser.2014.08.007

Choi, T.Y. and Chu, R. (2001), "Determinants of hotel guests' satisfaction and repeat patronage in the Hong Kong hotel industry", International Journal of Hospitality Management, Vol. 20, No. 3, pp. 277297, https://doi.org/10.1016/S0278-4319(01)00006-8

Chu, R.K.S. and Choi, T. (2000), "An importance-performance analysis of hotel selection factors in the Hong Kong hotel industry: A comparison of business and leisure travellers", Tourism Management, Vol. 21, No. 4, pp. 363-377, https://doi.org/10.1080/1331677X.2014.967537

Clarke, A. and Chen, W. (2007), International hospitality management: Concepts and cases. Elsevier, Amsterdam.

Cobanoglu, C., Berezina, K., Kasavana, M.L. and Erdem, M. (2011), "The impact of technology amenities on hotel guest overall satisfaction", Journal of Quality Assurance in Hospitality \& Tourism, Vol. 12, No. 4, pp. 272-288, https://doi.org/10.1080/1528008X.2011.541842

Costa, C. and Buhalis, D. (Eds.) (2006a), Tourism business frontiers: Consumers, products and industry, Elsevier, London.

Costa, C. and Buhalis, D. (Eds.) (2006b), Tourism management dynamics: Trends, management and tools, Elsevier, London.

Creswell, J.W. (2009), Research design: Qualitative, quantitative, and mixed methods approaches, Sage Publications, California.

Crnojevac, I.H., Gugić, J. and Karlovčan, S. (2010), "eTourism: A comparison of online and offline bookings and the importance of hotel attributes", Journal of Information and Organizational Sciences, Vol. 34, No. 1, pp. 41-54.

Crompton, J.L. (1979), "Motivations for pleasure vacation", Annals of Tourism Research, Vol. 6, No. 4, pp. 408-424, https://doi.org/10.1016/0160-7383(79)90004-5

Cronin, J.J., Brady, M.K. and Hult, G.T.M. (2000), "Assessing the effects of quality, value, and customer satisfaction on consumer behavioral intentions in service environments", Journal of Retailing, Vol. 76, No. 2, pp. 193-218, http://dx.doi.org/10.1016/S0022-4359(00)00028-2

Dolnicar, S. and Otter, T. (2003), "Which hotel attributes matter? A review of previous and a framework for future research", in 9th Annual Conference of the Asia Pacific Tourism Association, University of Technology, Sidney, pp. 176-188.

Dwyer, L., Edwards, D., Mistilis, N., Roman, C., Scott, N. and Cooper, C. (2008), Megatrends underpinning tourism to 2020: Analysis of key drivers for change, CRC for Sustainable Tourism.

Euromonitor. (2014), "Trends shaping online travel", available at https://www.tti.org/wp-content/uploads/2016/11/Caroline_Bremner_Euromonitor.pdf

Fesenmaier, D.R. and Gretzel, U. (2004), "Searching for experience: Tecnhology-related trends shaping the future of tourism, in Weiermair, K. and Mathies, C. (Eds.), The tourism and leisure industry: Shaping the future, Haworth Hospitality Press, New York, pp. 285-300.

Fodness, D. and Murray, B. (1997), "Tourist information search", Annals of Tourism Research, Vol. 24, No. 3, pp. 503-523, http://dx.doi.org/10.1016/S0160-7383(97)00009-1

Fodness, D. and Murray, B. (1999), "A model of tourist information search behaviour", Journal of Travel Research, Vol. 37, No. 3, pp. 220-230, https://doi.org/10.1177/004728759903700302

Goeldner, C.R., Ritchie, J.R.B. and McIntosh, R. (1995), Tourism principles, practices, philosophies (7th ed.), John Wiley \& Sons.

Gronflaten, O. (2009), "Predicting travelers' choice of information sources and information channels", Journal of Travel Research, Vol. 48, No. 2, pp. 230-244, https://doi.org/10.1177/0047287509332333

Hair, J.F., Bush, R.P. and Ortinau, D.J. (2003), Marketing research: Within a changing information environment, McGraw-Hill, Irwin.

Han, H., Hsu, L.-T.J., Lee, J.-S., \& Sheu, C. (2011), “Are lodging customers ready to go green? An examination of attitudes, demographics, and eco-friendly intentions", International Journal of Hospitality Management, Vol. 30, No. 2, pp. 345-355, https://doi.org/10.1016/j.ijhm.2010.07.008

Hernández, B., Jiménez, J. and José Martín, M. (2011), “Age, gender and income: Do they really moderate online shopping behaviour?", Online Information Review, Vol. 35, No. 1, pp. 113-133, https://doi.org/10.1108/14684521111113614

INE (2018), Estatísticas do turismo, Instituto Nacional de Estatística, Lisboa. 
ToSEE - Tourism in Southern and Eastern Europe, Vol. 5, pp. 139-162, 2019

Z. Breda, C. Pacheco, G. Dinis: FUTURE TRENDS IN THE HOSPITALITY INDUSTRY: AN ...

Jennings, G. (2010), Tourism research (2th ed.), John Wiley \& Sons, Milton.

Jun, S.H., Vogt, C.A. and MacKay, K.J. (2010), "Online information search strategies: A focus on flights and accommodations", Journal of Travel \& Tourism Marketing, Vol. 27, No. 6, pp. 579-595, https://doi.org/10.1080/10548408.2010.507151

Kandampully, J., Juwaheer, T.D. and Hu, H.-H. (2011), "The influence of a hotel firm's quality of service and image and its effect on tourism customer loyalty", International Journal of Hospitality \& Tourism Administration, Vol. 12, No. 1, pp. 21-42, https://doi.org/10.1080/15256480.2011.540976

Kang, K.H., Stein, L., Heo, C.Y. and Lee, S. (2012), "Consumers' willingness to pay for green initiatives of the hotel industry", International Journal of Hospitality Management, Vol. 31, No. 2, pp. 564-572, https://doi.org/10.1016/j.ijhm.2011.08.001

Knutson, B.J. (1988), "Frequent travelers: Making them happy and bringing them back", The Cornell Hotel and Restaurant Administration Quarterly, Vol. 29, No. 1, pp. 82-87, https://doi.org/10.1177/001088048802900121

Kotler, P. and Keller, K. (2006), Admnistração de marketing (12ª ed.), Person Education, Brasil

Kotler, P., Madariaga Miranda, J.G, Flores Zamora, J., Bowen, J. and Makens, J.C. (2011), Marketing turístico (5th ed.), Pearson Educación, Madrid.

LeBlanc, G. and Nguyen, N. (1996), "An examination of the factors that signal hotel image to travellers", Journal of Vacation Marketing, Vol. 3, No. 1, pp. 32-42, https://doi.org/10.1177/135676679600300103

Lockyer, T. (2005), "Understanding the dynamics of the hotel accommodation purchase decision", International Journal of Contemporary Hospitality Management, Vol. 17, No. 6, pp. 481-492, https://doi.org/10.1108/09596110510612121

Lopes, R. (2015), “Credibilidade dos comentários online e qualidade do website: Implicações na tomada de decisão dos turistas", Master Dissertation, Universidade de Aveiro, Aveiro.

Lopez, J., Perez, D., Zalama, E. and Gomez, J. (2013), "BellBot: A hotel assistant system using mobile robots", International Journal of Advanced Robotic Systems, Vol. 10, No. 1, pp. 1-11, https://doi.org/10.5772/54954

Mathieson, A. and Wall, G. (1982), Tourism: Economic, Physical, and Social Impacts, Longman, Harlow.

Mccleary, K.W., Weaver, P.A. and Hutchinson, J.C. (1993), "Hotel selection factors as they relate to business travel situations", Journal of Travel Research, Vol. 32, No. 2, pp. 42-48, https://doi.org/10.1177/004728759303200206

Middleton, V.T.C. and Clarke, J. (2001), Marketing in travel and tourism (4th ed.), Butterworth-Heinemann, Burlington.

Muller, C. (2010), "Hospitality technology: A review and reflection", Worldwide Hospitality and Tourism Themes, Vol. 2, No. 1, pp. 9-19, https://doi.org/10.1108/17554211011012568

Murphy, H.C., Chen, M.-M. and Cossutta, M. (2016), "An investigation of multiple devices and information sources used in the hotel booking process", Tourism Management, Vol. 52, pp. 44-51, https://doi.org/10.1016/j.tourman.2015.06.004

Neuhofer, B., Buhalis, D. and Ladkin, A. (2015), "Smart technologies for personalized experiences: A case study in the hospitality domain", Electronic Markets, Vol. 25, No. 3, pp. 243-254 https://doi.org/10.1007/s12525-015-0182-1

Oh, H., Fiore, A.M. and Jeoung, M. (2007), "Measuring experience economy concepts: Tourism applications", Journal of Travel Research, Vol. 46, No. 2, pp. 119-132, https://doi.org/10.1177/0047287507304039

Peiró-Signes, Segarra-Oña, Verma, Mondéjar-Jiménez, J. and Vargas-Vargas, M. (2014), “The impact of environmental certification on hotel guest ratings", Cornell Hospitality Quarterly, Vol. 55, No. 1, pp. 40-51.

Pine, B.J. and Gilmore, J.H. (1998), "Welcome to the experience economy”, Harvard Business Review, Vol. 76, No. 4, pp. 97-105.

Pine, B.J. and Gilmore, J.H. (2011), The experience economy, Harvard Business School Press, Boston.

Pirnar, I., Icoz, O. and Icoz, O. (2010), "The new tourist: Impacts on the hospitality marketing strategies", In Passion for Hospitality Excellence, EuroCHRIE, Amsterdam, p. 12.

Plog, S.C. (1974), "Why destination areas rise and fall in popularity", Cornell Hotel and Restaurant Administration Quarterly, Vol. 14, No. 4, pp. 55-58, https://doi.org/10.1177/0010880401423001

Poon, A. (1993), Tourism, technology and competitive strategies, C.A.B. International, New York.

Poon, W. and Lock-Teng Low, K. (2005), “Are travellers satisfied with Malaysian hotels?", International Journal of Contemporary Hospitality Management, Vol. 17, No. 3, pp. 217-227, https://doi.org/10.1108/09596110510591909 
ToSEE - Tourism in Southern and Eastern Europe, Vol. 5, pp. 139-162, 2019

Z. Breda, C. Pacheco, G. Dinis: FUTURE TRENDS IN THE HOSPITALITY INDUSTRY: AN ...

Qi, S., Law, R. and Buhalis, D. (2013), "Who booked five-star hotels in Macau? A study of hotel guests' online booking intention", Journal of Hospitality and Tourism Management, Vol. 20, pp. 76-83, http://doi.org/10.1016/j.jhtm.2013.05.002

Radojevic, T., Stanisic, N. and Stanic, N. (2015), "Ensuring positive feedback: Factors that influence customer satisfaction in the contemporary hospitality industry", Tourism Management, Vol. 51, pp. 13-21, https://doi.org/10.1016/j.tourman.2015.04.002

Rivers, M.J., Toh, R.S. and Alaoui, M. (1991), "Frequent-stayer programs: The demographic, behavioral, and attitudinal characteristics of hotel steady sleepers", Journal of Travel Research, Vol. 30, No. 2, pp. 41-45, https://doi.org/10.1177/004728759103000209

Saleh, F. and Ryan, C. (1992), "Client perceptions of hotels, a multi-attribute approach", Tourism Management, Vol. 13, No. 2, pp. 163-168, https://doi.org/10.1016/0261-5177(92)90058-F

Serra Cantallops, A. and Salvi, F. (2014), "New consumer behavior: A review of research on eWOM and hotels", International Journal of Hospitality Management, Vol. 36, pp. 41-51, https://doi.org/10.1016/j.ijhm.2013.08.007

Schmitt, N. (1996), "Uses and abuses of coefficient alpha", Psychological Assessment, Vol. 8, No. 4, pp. 350353, http://dx.doi.org/10.1037/1040-3590.8.4.350

Sparks, B.A. and Browning, V. (2011), "The impact of online reviews on hotel booking intentions and perception of trust", Tourism Management, Vol. 32, No. 6, pp. 1310-1323, https://doi.org/10.1016/j.tourman.2010.12.011

Swarbrooke, J. and Horner, S. (2007), Consumer behaviour in tourism, Butterworth-Heinemann, Burlington.

Toh, R.S., DeKay, C.F. and Raven, P. (2011), "Travel planning: Searching for and booking hotels on the Internet”, Cornell Hospitality Quarterly, Vol. 52, No. 4, pp. 388-398, https://doi.org/10.1177/1938965511418779

UNWTO (2002), Tourism 2020: Vision global forecasts and profile of market segments, World Tourism Organization, Madrid.

UNWTO (2011), Tourism towards 2030: Global overview, World Tourism Organization, Madrid.

UNWTO (2019), "International tourism results 2018 and outlook 2019", available at http://marketintelligence.unwto.org/barometer/january-2019-volume-17

Veal, A.J. (2006), Research methods for leisure and tourism: A pratical guide (3rd ed.), Pearson Education, Essex.

Verma, R., Stock, D. and McCarthy, L. (2012), "Customer preferences for online, social media, and mobile innovations in the hospitality industry", Cornell Hospitality Quarterly, Vol. 53, No. 3, pp. 183-186.

Vermeulen, I.E. and Seegers, D. (2009), "Tried and tested: The impact of online hotel reviews on consumer consideration", Tourism Management, Vol. 30, No. 1, pp. 123-127, https://doi.org/10.1016/j.tourman.2008.04.008

Wall, G. and Mathieson, A. (2006), Tourism: Change, impacts, and opportunities. Pearson Prentice Hall, New York.

Walls, A., Okumus, F., Wang, Y. and Kwun, D.J.-W. (2011), "Understanding the consumer experience: An exploratory study of luxury hotels", Journal of Hospitality Marketing \& Management, Vol. 20, No. 2, pp. 166-197, https://doi.org/10.1080/19368623.2011.536074

Wilensky, L. and Buttle, F. (1988), "A multivariate analysis of hotel benefit bundles and choice trade-offs", International Journal of Hospitality Management, Vol. 7, No. 1, pp. 29-41, https://doi.org/10.1016/0278-4319(88)90008-4

Wilkins, H. (2010), "Using Importance-Performance Analysis to appreciate satisfaction in hotels", Journal of Hospitality Marketing \& Management, Vol. 19, No. 8, pp. 866-888, https://doi.org/10.1080/19368623.2010.514554

Woodside, A.G., Frey, L.L. and Daly, R.T. (1989), "Linking service quality, customer satisfaction, and behavioral intention", Journal of Health Care Marketing, Vol. 9, No. 4, pp. 5-17.

Xiang, Z. and Gretzel, U. (2010), "Role of social media in online travel information search", Tourism Management, Vol. 31, No. 2, pp. 179-188, https://doi.org/10.1016/j.tourman.2009.02.016

Xiang, Z., Wang, D., O’Leary, J.T. and Fesenmaier, D.R. (2014), “Adapting to the Internet: Trends in travelers' use of the Web for trip planning", Journal of Travel Research, Vol. 54, No. 4, pp. 511-527, https://doi.org/10.1177/0047287514522883

Yavas, U. and Babakus, E. (2003), "What do guests look for in a hotel?, Services Marketing Quarterly, Vol. 25 , No. 2, pp. 1-9.

Yen, C.-L. and Tang, C.-H. (2015), "Hotel attribute performance, eWOM motivations, and media choice", International Journal of Hospitality Management, Vol. 46, 79-88, https://doi.org/10.1016/j.ijhm.2015.01.003

Yeoman, I. (2006), “Tomorrow's: World, consumer and tourist”, Journal of Vacation Marketing, Vol. 12, No. 2, pp. 174-190, https://doi.org/10.1177/1356766706062164 
ToSEE - Tourism in Southern and Eastern Europe, Vol. 5, pp. 139-162, 2019

Z. Breda, C. Pacheco, G. Dinis: FUTURE TRENDS IN THE HOSPITALITY INDUSTRY: AN ...

Yeoman, I. (2012), 2050 tomorrow's tourism, Channel View Publications, Bristol.

Yoon, Y. and Uysal, M. (2005), "An examination of the effects of motivation and satisfaction on destination loyalty: A structural model”, Tourism Management, Vol. 26, No. 1, pp. 45-56, https://doi.org/10.1016/j.tourman.2003.08.016

Zeithaml, V.A., Parasuraman, A. and Berry, L.L. (1985), "Problems and strategies in services marketing", Journal of Marketing, Vol. 49, No. 2, pp. 33-46, https://doi.org/10.2307/1251563

Zhou, L., Ye, S., Pearce, P.L. and Wu, M.-Y. (2014), "Refreshing hotel satisfaction studies by reconfiguring customer review data", International Journal of Hospitality Management, Vol. 38, pp. 1-10, https://doi.org/10.1016/j.ijhm.2013.12.004

Zélia Breda, $\mathrm{PhD}$, Assistant Professor

University of Aveiro

Department of Economics, Management, Industrial Engineering and Tourism

Research Unit on Governance, Competitiveness and Public Policies

Campus Universitário de Santiago, 3810-193 Aveiro, Portugal

Phone: +351234370361

E-mail: zelia@ua.pt

Catarina Pacheco, MSc

University of Aveiro

Department of Economics, Management, Industrial Engineering and Tourism

Campus Universitário de Santiago, 3810-193 Aveiro, Portugal

Phone: +351234370361

E-mail: catarinapacheco@ua.pt

Gorete Dinis, $\mathrm{PhD}$, Adjunct Professor

Polytechnic Institute of Portalegre

School of Education and Social Sciences

Research Unit on Governance, Competitiveness and Public Policies

Praça da República, 23-25, 7300-109 Portalegre, Portugal

Phone: +351245 339400

E-mail: gdinis@ipportalegre.pt 